\title{
The Eurasian Group on Combating Money Laundering and financing of terrorism as a component of international anti-money laundering system
}

\section{Yurieva A.}

Diplomatic Academy of Russian Foreign Ministry, Ostozhenka 53/2, stroenie 1, Moscow, 119021, Russia

\section{Abstract}

This article is about the Eurasian Group on Combating Money Laundering and financing of terrorism. The history of group is studied, as well as its structure and functions. The examples of the results of group's activities are presented, the conclusion is made about its role in the region and the role of Russia in group's development.

Corresponding Author:

Yurieva A.

Alyo-yureva@yandex.ru

Received: 11 December 2017

Accepted: 20 January 2018

Published: 13 February 2018

Publishing services provided by Knowledge E

(c) Yurieva A.. This article is distributed under the terms of the Creative Commons

Attribution License, which permits unrestricted use and redistribution provided that the original author and source are credited.

Selection and Peer-review under the responsibility of the FinTech and RegTech: Possibilities, Threats and Risks of Financial Technologies Conference Committee.
Keywords: Combating Money Laundering and financing of terrorism, FATF, FATFstyle regional body, The Eurasian Group on Combating Money Laundering and financing of terrorism, Technical assistance and training, The International training and methodology center for financial monitoring

States in modern world often face different global threats and challenges. One of such challenges is transnational organized crime and terrorism, which threatens the development of national economies and often even the existence of national jurisdictions. And it is the illegal incomes and their legalization that fuel organized crime and terrorism.

In order to fight against the illegal means' turnover and to develop global standards for combating money laundering and financing of terrorism (AML/CFT) The Financial Action Task Force (FATF) was founded by the G-7 countries in 1989. Today FATF has 35 states and 2 organizations as its members and 1 state and 20 organization as observers. It cooperates with the UN, Council of Europe, World Bank, European Bank for Reconstruction and Development, International Monetary Fund, Interpol, Europol, Customs Cooperative council and other international organizations as well as international professional network of Financial Intelligence Units (FIU) - the Egmont group (Federal Financial Monitoring Service official website data http://www.fedsfm.ru/activity/fatf).

\section{S OPEN ACCESS}


FATF has a status of intergovernmental organization. It develops and implements international standards for combating the money laundering and financing of terrorism as well as assesses the level of compliance of AML/CFT national systems to these standards. International standards consist of 40 recommendations and 9 special recommendations for countering the financing of terrorism, implementation of which FATF promotes in national law systems of all the states. It also monitors the national anti-laundering systems for their compliance with the recommendations.

Russia started its way of joining the FATF with entering its "black list", due to identified deficiencies in national AML/CFT system. After passing a round of mutual assessment of anti-laundering system Russia was excluded from the list and joined the Group in 2003. Today Russia is one of the FATF member states, which have a huge influence in the international fora. Due to the state's activity and high international authority in AML/CFT Russian representative in FATF Vladimir Nechaev became the president of the organization in 2013-2014. It was Russia's initiative to create the new FATF-style regional body - The Eurasian group on combating money laundering and financing of terrorism (EAG) - with the aim of promoting implementation of the FATF standards in Eurasian region.

The first proposal about the establishing of the EAG was made by Russia in 2003 during the FATF plenary session. This issue had previously been discussed during the international meeting "Cooperation of CIS member states in combating money laundering and financing of terrorism" with representatives of Russia, China, CIS member-states and several international organizations taking part. Russia got the support and introduced the project to the CIS Council of Foreign Ministers, and it has been approved. Upon their recommendation the States, interested in establishing such a regional group, held a constituent conference on October 6. 2004. (Declaration on establishing the Eurasian group on combating money laundering and financing of terrorism) Russia took the responsibility for provision and financing of the EAG secretariat (The agreement between the government of the Russian Federation and the Eurasian group on combating money laundering and financing of terrorism on the conditions of its residence in Russian Federation.).

The EAG has become one of the 8 FATF- style regional bodies with Russia, Belarus, Kazakhstan, China, Kyrgyzstan and Tajikistan as member-states. They were later joined by Uzbekistan, India and Turkmenistan. In June 2011 the constituent conference was held in Moscow, where "The Agreement on the Eurasian group on combating money laundering and financing of terrorism" was signed, thus giving the EAG status of regional intergovernmental organization. 
According to the "Agreement", plenary session of authorized representatives of the member-states is the supreme body of the EAG, and such session is held not less than once a year. Under the guidance of the EAG Chairman the urgent issues, related to the common interests of the EAG member-states are discussed, strategy and priorities in combating the financing of terrorism, studying and implementing new AML/CFT trends and methods are defined, and the compliance of the national anti-laundering systems with the international standards is monitored. Secretariat is the working body of the EAG. It performs administrative and technical functions that help in implementation of the plenary session's decisions and Chairman's instructions. According to the regulation, Secretariat headquarters are situated in Moscow.

In addition to the Secretariat, working groups for specific activities are created by the plenary session's decision. According to the working groups' mandate, plenary session defines their order of formation, functions and accountability. There are currently three permanent working groups:

- Working group on mutual assessment and law issues;

- Working group on typologies and countering terrorism and organized crime;

- Working group on technical assistance;

WGTA could be distinguished from the other EAG working groups by its functions. It performs many tasks, among them - assessment of the EAG member-states' needs in technical assistance in cooperation with other working groups and international organizations; interaction with concerned EAG observer states and organizations as well as the organizations, which are part of the EAG assistance infrastructure, including ITMCFM, for coordination of the EAG member-states' technical support and carrying out of the educational activities, based on the needs, identified during the assessment and the mutual evaluations reports. WGTA activity plays an important role in development of the anti-laundering system in the AEG member-states. Russia has been adopting and accumulating the experience of the FATF member-states and FIUs for many years, and it also has been developing its own IT system. Now it is ready to interact with concerned states to exchange experience and promote its own projects. However, technical assistance is not the only field of interaction between the EAG memberstates.

FIUs, enforcement authorities and their interaction for countering the terrorism and organized crime also play a significant role. Since 2007 FIU have provided all the necessary data for "Canal" anti-drug operation, conducted by the Collective Security Treaty 
Organization. The main goal of the operation is organization of departments' coordinated work to identify and prevent the illegal drug trafficking from Afghanistan to CSTO and EAG member-states. In order to achieve this goal, intelligence units exchange information about the persons, facts and objects, related to drug trafficking and legalization of illegal incomes. The analysis of such data allows them to find the exact kingpins. The scale of the operation is increasing annually, as well as the volumes of the confiscated drugs. Due to the coordinated actions of the enforcement authorities of EAG member-states several channels have been disrupted. According to the results of the operation "Canal - Zapadnyy zaslon", conducted from May 29. to June 2, 2017, more than 16,7 tons of different drugs have been confiscated, 808 drug crimes have been unveiled and more than 800 criminal proceedings have been initiated by the anti-drug departments of the CSTO member-states, with support from FIU from EAG memberand observer states, such as Russia, Armenia, Belarus, Kazakhstan, Kyrgyzstan and Tajikistan. («Financial security» magazine. №17 June 2017)

Drug trafficking remains one of the important issues for the EAG member states, but it is not the only priority in the plenary sessions' discussions.

According to the results of the EAG $26^{\text {th }}$ plenary session, which took place in Bishkek, Kyrgyzstan from May 22. to May 26., the agenda included the following issues: combating the financing of terrorism, technical assistance, mutual assessments and legal issues, typologies. The participants highlighted the necessity of the efforts' consolidation in AML/CFT among the FIU and on the enforcement, supervisory and fiscal authorities of the EAG member states. The contribution of ITMCFM to preparations for the next round of EAG mutual evaluations and personnel training in AML/CFT was highly appreciated. ITMCFM presented the technical assistance project for increase of the volume of such assistance to the member states. This project proposes the organizing of the thematic events for education and exchange of the experience in $\mathrm{AML} / \mathrm{CFT}$.

However, it is possible to detect new risks, which EAG member-states could face relatively soon. Use of digital currencies and payments, made with these "virtual money" can bear potential risks not only for financial institutions, but also for the national AML/CFT systems as their origin can't be identified.

During the last 5 years cyber currency, such as bitcoin, litecion and others has transformed from some sort of amusement of IT specialists and geeks to a possible object for investments and a new Gold fever. The cumulative capitalization of cryptocurrencies by November, 2017 has exceeded $\$ 200$ billion. 
Bitcoin, along with the others digital currencies has no binding to values. That is why its fluctuation in exchange depends only on the interest, attracted by digital money.

The EAG member states adhere to a flexible approach to regulation of the cryptocurrency market. For example, in China the legislative approach in this field is in a process of formation. China has become the first state to take a strict approach to ICO (Initial coin offering), and then to bitcoin and to exchanges, which trade in crypto currency. In PRC the digital currency is described as a virtual item (non-monetary digital asset). The ban on ICO is in force since September, 2017. Imposition of this ban has significantly shaken quotations in the international market of cryptocurrencies. In the meantime, possession of crypto-currency by individuals and crypto-currency transactions between them are allowed. In spite of strict restrictions on operations with Bitcoin, China controls Bitcoin as a payments system through its manufacturers of the specialized equipment for mining.

Insecurity of cryptocurrencies along with the high speculative interest and the increasing number of roguish schemes bear the risks for citizens and financial systems. In this regard it is offered to consider a question of risks of virtual currencies at the session of the EAG working group.

In just 13 years the Eurasian group on combating money laundering and financing of terrorism has evolved from the Russian idea about the regional FATF-like group to the independent mechanism, which successfully operates within the region and outside of it, contributing to the international cooperation in AML/CFT. The exchange of the experience, information and knowledge helps EAG member states to adapt and improve the AML/CFT internal systems in compliance with the international standards. And joint efforts allow them to combat the financial crimes, financing of terrorism and drug trafficking.

\section{References}

[1] Declaration on establishing the Eurasian group on combating money laundering and financing of terrorism. Moscow, October 6. 2004.

[2] International system of combating money laundering and financing of terrorism. Zubkov V.A. Osipov S.K. Moscow, 2008.

[3] International standards on money laundering, financing of terrorism and financing the proliferation of weapons of mass destruction. FATF recommendations. Translated from English. ITMCFM. 2012.

[4] The report on the EAG $26^{\text {th }}$ plenary session of working groups. Bishkek, May 2017. 
[5] Regulation on the EAG Secretariat. June 16. 2011.

[6] Agreement on the Eurasian group on combating money laundering and financing of terrorism. Moscow, June 16. 2011.

[7] «Financial security» magazine. №17 June 2017 